\title{
PITUITARY LUTEINIZING HORMONE CONTENT OF UNMATED, PSEUDOPREGNANT, PREGNANT AND PROGESTERONE-TREATED RABBITS
}

\author{
A. P. LABHSETWAR* \\ Imperial Chemical Industries Limited, Pharmaceuticals Division, \\ Alderley Park, Macclesfield, Cheshire
}

(Received 17th September 1971, accepted 10th Fanuary 1972)

\begin{abstract}
Summary. The LH content of the pituitary of rabbits in various reproductive states was assayed by the ovarian ascorbic acid depletion method. It was highest in unmated rabbits and decreased significantly $(P<0.01)$ during both pseudopregnancy and pregnancy. Administration of progesterone $(20 \mathrm{mg} /$ day for 10 days) reduced pituitary $\mathrm{LH}$ in unmated rabbits to levels similar to those found during pseudopregnancy and pregnancy. It is inferred that the capacity of the pituitary gland to accumulate LH during pseudopregnancy and pregnancy decreases mainly as a result of secretion of progesterone.
\end{abstract}

The rabbit ovulates after mating and becomes either pseudopregnant or pregnant (Hammond, 1925). The cL formed require oestrogen for their functional maintenance (Robson, 1937). Secretion of the steroid is believed to be controlled by LH so that this gonadotrophin is luteotrophic in the rabbit (Kilpatrick, Armstrong \& Greep, 1964). Therefore, it seemed of interest to determine the fluctuations, if any, in the pituitary LH stores during pseudopregnancy and pregnancy and following treatment with progesterone. Although Hill (1934) and Friedman \& Friedman (1939) measured pituitary LH in rabbits, a quantitative assay such as the ovarian ascorbic acid depletion (OAAD) method (Parlow, 1961) was not available to these workers.

Thirty-five adult Dutch belted rabbits weighing between 1.5 and $2.5 \mathrm{~kg}$ were obtained from a commercial source and housed individually in a temperature-controlled room. They were fed a standard diet. Pseudopregnancy was induced by intravenous injection of 25 i.u. HCG (A.P.L., Ayerst Lab., N.Y.) and rabbits were killed on Days 1 ( 1 day after the HCG injection), 4, 8 and 12 . Other rabbits were killed on Days 5, 13, 20 and 30 of pregnancy (Day of mating $=0$ ) and Day 9 post partum. Each group, except that killed on Day 1 of pregnancy (two rabbits only), included three animals. All rabbits were killed with an overdose of chloroform and the anterior pituitaries were removed and weighed. The glands were pooled within each group and kept frozen $\left(-20^{\circ} \mathrm{C}\right)$ until assayed for LH. The ovaries were examined for the number of CL. The

\footnotetext{
* Present address: Worcester Foundation for Experimental Biology, 222 Maple Avenue, Shrewsbury,
} Mass. 01545, U.S.A. 
mean number of CL at different stages of pseudopregnancy varied between 7 and 10 and that of pregnancy between 6 and 10 . The experiment with pseudopregnant rabbits was carried out in November while that with pregnant animals was performed between March and June of the following year. In each case, a group of unmated rabbits served as controls.

In the final experiment, one group of five rabbits was injected daily with $20 \mathrm{mg}$ progesterone s.c. in oil for 10 days, while the other group of four animals served as control and received oil injections only. One day after the last injection, the rabbits were killed and the pituitaries were harvested. This experiment was also performed in April of the same year.

Each pool of frozen pituitary glands was thawed, homogenized in saline and assayed for LH content by the OAAD method using conditions already described (Labhsetwar, 1969). The assay rats were of Alderley Park strain 1, originally derived from Wistar rats. All injections were made through a tail vein in conscious animals and ovaries were collected for ascorbic acid determination $4 \mathrm{hr}$ after the injection. In the dosages used, no toxic effects of the injected material were detected. Each assay included two doses of each of four test preparations (five assay rats/dose), one of which was always from unmated controls. Considerable efforts were made to find suitable doses of pituitary homogenates, which would yield dose-response lines parallel with the standard (NIH-LH-S-14). The glands of unmated control rabbits were usually assayed in doses of 0.05 and $0.25 \mathrm{mg}$ (wet weight) and those of pseudopregnant, pregnant and progesterone-treated rabbits in doses of 0.1 and $0.5 \mathrm{mg}$. The standard $\mathrm{LH}$ was used in doses of 0.4 and $2 \mu \mathrm{g} /$ assay rat. The relative potency, $95 \%$ confidence limits and indices of precision were calculated by the method described by Gaddum (1953) for parallel line assays. Out of a total of twelve assays, three were discarded because of lack of parallelism. The pituitary pools from pseudopregnant and progesterone-treated rabbits and respective unmated control rabbits were assayed three times but the pituitary glands from the pregnant rabbits were assayed only once.

The results (Table 1) show that pituitaries of rabbits killed in November as unmated controls for pseudopregnant animals (Exp. 1) contained far more LH than those of animals killed between March and June as controls for the pregnant animals (Exp. 2) or in April as controls (Exp. 3) for the progesteronetreated rabbits $(P<0.01)$. The last two groups were comparable $(P>0.05)$. This appears to be a reflection of a seasonal variation rather than alterations in the sensitivity of assay rats to LH since the use of the reference standard would presumably minimize or eliminate the latter. Existence of seasonal variation in LH content was reported earlier by Friedman \& Friedman (1939).

There was a significant decline in the pituitary ${ }_{\text {LH }}$ level during pseudopregnancy $(P<0.05)$ when compared with the unmated control group (Exp. 1). This observation contrasts with that of Hill (1934) who, using ovulation induction in oestrous rabbits as a bioassay for $\mathbf{L H}$, reported a marked rise in pituitary LH stores in the middle of pseudopregnancy. In the present study, pituitary glands from the pregnant rabbits also showed a decline in LH content, although the glands were assayed only once (Exp. 2, Table 1). The mean LH level during pregnancy was significantly below that of contemporary 
TABLE 1

PITUITARY LH LEVELS OF UNMATED, PSEUDOPREGNANT, PREGNANT, post-partum AND PROGESTERONE-TREATED RABBITS

\begin{tabular}{|c|c|c|c|c|}
\hline $\begin{array}{l}\text { Exp. } \\
\text { no. }\end{array}$ & $\begin{array}{l}\text { Reproductive } \\
\text { state }\end{array}$ & Concentration $\S$ & $\begin{array}{c}\text { Content } \\
(\mu \mathrm{g} / \text { gland })\end{array}$ & $\lambda \ddagger$ \\
\hline \multirow[t]{6}{*}{1} & $\begin{array}{l}\text { Unmated rabbits } \\
\text { killed in November }\end{array}$ & $\begin{array}{l}27(13 \text { to } 57) \dagger \\
53(26 \text { to } 108) \\
44(21 \text { to } 92)\end{array}$ & $\begin{array}{l}475 \\
910 \\
761\end{array}$ & $\begin{array}{l}0.301 \\
0.280 \\
0.298\end{array}$ \\
\hline & Mean \pm S.E. & $41 \pm 8$ & $715 \pm 128$ & \\
\hline & $\begin{array}{l}\text { Pseudopregnant } \\
\text { Day } 1\end{array}$ & $\begin{array}{l}7(4 \text { to } 14) \\
41(19 \text { to } 90) \\
13(6 \text { to } 25) \\
20 \pm 10\end{array}$ & $\begin{array}{c}109 \\
592 \\
185 \\
295 \pm 150\end{array}$ & $\begin{array}{l}0.301 \\
0.280 \\
0.298\end{array}$ \\
\hline & $\begin{array}{l}\text { Day } 4 \\
\text { Mean } \pm \text { S.E. }\end{array}$ & $\begin{array}{l}8(4 \text { to } 16) \\
14(7 \text { to } 28) \\
10(5 \text { to } 19) \\
11 \pm 2^{*}\end{array}$ & $\begin{array}{c}139 \\
227 \\
161 \\
176 \pm 26^{*}\end{array}$ & $\begin{array}{l}0.301 \\
0.298 \\
0.281\end{array}$ \\
\hline & $\begin{array}{l}\text { Day } 8 \\
\text { Mean } \pm \text { S.E. }\end{array}$ & $\begin{array}{l}7(4 \text { to } 13) \\
19(9 \text { to } 40) \\
5(3 \text { to } 8) \\
10 \pm 4^{*}\end{array}$ & $\begin{array}{c}86 \\
229 \\
55 \\
123 \pm 53^{*}\end{array}$ & $\begin{array}{l}0.280 \\
0.298 \\
0.280\end{array}$ \\
\hline & $\begin{array}{l}\text { Day } 12 \\
\text { Mean } \pm \text { S.E. }\end{array}$ & $\begin{aligned} 11(5 \text { to } 21) \\
9(5 \text { to } 18) \\
10(5 \text { to } 21) \\
10 \pm 1^{*}\end{aligned}$ & $\begin{array}{c}142 \\
131 \\
134 \\
136 \pm 3^{*}\end{array}$ & $\begin{array}{l}0.301 \\
0.280 \\
0.328\end{array}$ \\
\hline \multirow[t]{2}{*}{2} & $\begin{array}{l}\text { Unmated rabbits } \\
\text { killed in March- } \\
\text { June } \\
\quad \text { Mean } \pm \text { S.E. }\end{array}$ & $\begin{array}{l}13(8 \text { to } 22) \\
12(6 \text { to } 24) \\
12(7 \text { to } 19) \\
12 \pm 0 \cdot 3^{*}\end{array}$ & $\begin{array}{c}323 \\
299 \\
285 \\
302 \pm 11 *\end{array}$ & $\begin{array}{l}0 \cdot 238 \\
0 \cdot 312 \\
0 \cdot 236\end{array}$ \\
\hline & $\begin{array}{c}\text { Pregnant } \\
\text { Day } 1 \\
5 \\
9 \\
13 \\
20 \\
25 \\
30 \\
\text { Post partum } \\
\text { Day } 9 \\
\text { Mean } \pm \text { S.E. }\end{array}$ & $\begin{array}{l}\text { Invalid } \\
4(2 \text { to } 6) \\
\text { Invalid } \\
3(2 \text { to } 7) \\
7(4 \text { to } 12) \\
4(2 \text { to } 8) \\
5(3 \text { to } 8) \\
5(3 \text { to } 8) \\
5 \pm 1^{* *}\end{array}$ & $\begin{array}{c}\overline{79} \\
\overline{64} \\
122 \\
104 \\
103 \\
90 \\
94 \pm 8^{* *}\end{array}$ & $\begin{array}{l}0 . \overline{238} \\
\overline{0.312} \\
0.238 \\
0.312 \\
0.236 \\
0.236\end{array}$ \\
\hline \multirow[t]{2}{*}{3} & $\begin{array}{l}\text { Unmated control } \\
\text { killed in March- } \\
\text { June } \\
\quad \text { Mean } \pm \text { S.E. }\end{array}$ & $\begin{array}{l}5(4 \text { to } 8) \\
15(9 \text { to } 25) \\
14(5 \text { to } 39) \\
11 \pm 3^{*}\end{array}$ & $\begin{array}{c}127 \\
369 \\
289 \\
262 \pm 71^{*}\end{array}$ & $\begin{array}{l}0.200 \\
0.233 \\
0.332\end{array}$ \\
\hline & $\begin{array}{l}\text { Progesterone } \\
20 \mathrm{mg} / \text { day for } 10 \\
\text { days } \\
\quad \text { Mean } \pm \text { S.E. }\end{array}$ & $\begin{array}{l}3(2 \text { to } 4) \\
5(3 \text { to } 9) \\
5(2 \text { to } 12) \\
4 \pm 1\end{array}$ & $\begin{array}{c}68 \\
144 \\
123 \\
112 \pm 23\end{array}$ & $\begin{array}{l}0.200 \\
0.233 \\
0.332\end{array}$ \\
\hline
\end{tabular}

* $P<0.05 ; * * P<0.001$

$+95 \%$ confidence limits.

Index of precision.

$\$ \mu$ equivalents of N1H-LH-s-14/mg wet pituitary. 
controls $(P<0.001)$. Injection of progesterone into unmated rabbits induced a depletion of LH stores comparable to that found during pseudopregnancy (Exp. 3, Table 1). This observation suggests that progesterone secreted by the CL may have depleted pituitary LH stores during pseudopregnancy or pregnancy. Secretion of LH from the pituitary gland is minimal during pseudopregnancy since ovarian output of $20 \alpha$-dihydroprogesterone which is a sensitive indicator of LH secretion, declines during this period (Hilliard, Spies \& Sawyer, 1968). Therefore, it appears that the reduction in pituitary LH stores in the presence of progesterone, endogenous or exogenous, is due to a diminution in the synthesis of LH.

Hammond (1925) reported that mating during pregnancy is not followed by ovulation. This is unlikely to be due to the refractory state of the ovaries, since, during the second half of pregnancy, ovarian sensitivity to the ovulatory action of HCG is, if anything, enhanced (Adams, 1968). On the basis of the present results, it is likely that the ovulatory failure in response to mating to the absence of LH surge may be due to low pituitary reserves of LH.

The author is grateful to Miss Rosemary Chester for excellent technical assistance and the Endocrine Study Section, National Institutes of Health, Bethesda, Maryland, for reference standard.

\section{REFERENCES}

ADAMs, C. E. (1968) Ovarian response to human chorionic gonadotrophin and egg transport in the pregnant and post-parturient rabbit. $\mathcal{F}$. Endocr. 40, 101.

Friedman, M. H. \& FriedMan, G. (1939) Seasonal variations in the gonadotrophic hormone content of the rabbit pituitary. Endocrinology, 24, 626.

Gaddum, J. H. (1953) Simplified mathematics for bioassays. F. Pharm. Pharmac. 6, 345.

Hammond, J. (1925) Reproduction in the rabbit. Oliver \& Boyd, London.

HrLL, R. T. (1934) Variation in the activity of the rabbit hypophysis during the reproductive cycle. F. Physiol., Lond. 83, 129.

Hilliard, J., Spies, H. \& SAWYer, G. H. (1968) Cholesterol storage and progestin secretion during pregnancy and pseudopregnancy in the rabbit. Endocrinology, 82, 157.

Kilpatrick, K., Armstrong, D. T. \& Greep, R. O. (1964) Maintenance of the corpus luteum by gonadotropins in the hypophysectomized rabbit. Endocrinology, 74, 463.

LABHSETWAR, A. P. (1969) Influence of progesterone on the pituitary and plasma levels of LH and FSH in the female rat. Biol. Reprod. 1, 189.

PARLOw, A. F. (1961) Bioassay of pituitary luteinizing hormone by depletion of ovarian ascorbic acid. In: Human Pituitary Gonadotropins, p. 300. Ed. A. Albert. Thomas, Springfield, Illinois.

Rosson, J. M. (1937) Maintenance by oestrin of the luteal function in hypophysectomized rabbits. F. Physiol., Lond. 90, 435. 